\title{
The Effect of White Oyster Mushroom (Pleurotus ostreatus) Addubg on The Quality of Unproductive Quail (Coturnixcoturnix japonica) Abon Shredded Meat
}

\author{
Salam N. Aritonang, Allismawita, Siti Nur Dahlia \\ Animal Science Faculty, Andalas University Kampus Unand Limau Manis Padang
}

\begin{abstract}
How to cite this paper: Aritonang, S.N., Allismawita, Dahlia, S.N. (2019) The Effect of White Oyster Mushroom (Pleurotus ostreatus) Addubg on The Quality of Unproductive Quail (Coturnixcoturnix japonica) Abon Shredded Meat. International Journal of Food Science and Agriculture, 3(3), 232-236.
\end{abstract}

DOI: 10.26855/ijfsa.2019.09.012

*Corresponding author: Salam N. Aritonang, Animal Science Faculty, Andalas University Kampus Unand Limau Manis Padang.

Email: sn_aritonang@yahooo.com

\begin{abstract}
The research is the effect of white oyster mushroom (Pleurotus ostreatus) adding on the quality of Abon from unproductive quail. This study aim to utilizing quail meat into a preferred food and cheap price. Unproductive quail is a quail no longer in production and are generally 2.5 years old and a meat is tough. To increase the value of unproductivequail (Coturnixcoturnix japonica) we can process it into another products that high nutritional such as Abon. Abon known as typical Indonesian food made from meat cutlet and its price is expensive. To suppress the price of Abon to be inexpensive in its manufacture can be added with a mixture of vegetable such as white oyster mushroom (Pleurotus ostreatus) that taste like meat. In this study was used of $4000 \mathrm{~g}$ of unproductive quails meat and $600 \mathrm{~g}$ of white oyster mushroom (Pleurotusostreatus). The method use in this research is an experiment with Block Randomized Design (BRD) which consist of five treatments and four replications. The treatments are the adding of white oyster mushroom as much as $0 \%(\mathrm{~A}), 10 \%(\mathrm{~B}), 20 \%(\mathrm{C})$ and $30 \%(\mathrm{D})$. The variable was observed the content of moisture, protein, fat and the texture of unproductive quails Abon. The result of this research indicated that the adding of white oyster mushroom increased moisture and decreased a protein significantly $(\mathrm{P}<0.01)$ but didn't affected of fat and texture of unproductive quails Abon. Although the protein content decreases, it is still at the Abon quality recommended by the Indonesian National Standard for Abon. The adding of white oyster mushroom up to $30 \%$ in this research was permitted to produce unproductive quails Abon.
\end{abstract}

\section{Keywords}

abon, unproductive quails, white oyster mushroom, protein, texture

\section{Introduction}

Unproductive quails are male and females quail did not produce at the age of 30 months or 2.5 years, so economically when maintained continuously not benefit for farmers. Unproductive quail meat has high protein content $(21.1 \%)$ and a low fat content $(7.70 \%)$ [1]. To increase the economic value of unproductive quail (Coturnixcoturnix japonica) is by processing of unproductive quail meat to be high nutritional products like Abon or shredded meat.

Abon is a dry food made of sliced meat added with seasoning, then fried and finally pressed where the standard protein content at least $15 \%$ [2]. The Abon making is one way to extend the shelf life of meat. The moisture of Abon is much lower than fresh meat, such conditions can inhibit the growth and development of microbes [3].

Abon, known as the Indonesian foods which basically favored by the public. Usually the main ingredient for Abon 
is meat such as beef or chicken causing the price to be expensive. To reduce the use of meat so that Abon prices can be cheaper, then in it necessary to look for alternative ingredients that can be added in Abon making. Although Abon produced is cheaper, but its nutritional content is still qualified, the texture and taste still delicious. Generally, the mixture material that used were vegetable where it is inexpensive and easily to get it. A vegetable mixture that can be added is white oyster mushroom.

White oyster mushrooms are fungi that live in weathered wood, sawdust, straw waste or cotton waste [4]. White oyster mushroom (Pleurotus ostreatus ) has a good flavor even the taste likewise meat. White oyster mushroom has a high nutrient like protein (19-35\%), carbohydrates, vitamins and minerals, low in fat, and contains essential amino acids and contain fiber that can help digestion [5]. The existence of lignocellulosic fibers in the oyster mushrooms with a fiber content reached $7.4 \%-24.6 \%$ so it is safe to eat and good for digestion

Widyastuti and Istini [6] said that white oyster mushroom is very good for cardiovascular patients and to control cholesterol, and it is role as antitumor, antioxidant, and decreasing cholesterol. Other than that white oyster mushroom is used to prevent and control malnutrition, treatment of malnutrition and the treatment of iron deficiency. Sumarni [5] suggested Japan is currently examining the potential of white oyster mushrooms as a food that can prevent the onset of tumors .

\section{Materials and Research Methods}

This research used $4000 \mathrm{~g}$ unproductive quail meat and $600 \mathrm{~g}$ white oyster mushroom (Pleurotus ostreatus). The spices used in the Abon making such as thick coconut milk, onion, garlic, coriander, salt, pepper, and brown sugar. The research is an experiment using the block randomized design with 4 treatments and 5 replications $(800 \mathrm{~g}$ for each replication). The treatment was the adding of white oyster mushroom (Pleurotus ostreatus) as much as: $0 \%$ (A), $10 \%(\mathrm{~B})$, $20 \%(C)$ and $30 \%(D)$.

The variables were measured:

- Moisture content by drying method (thermogravimetri)

- Protein content by Kjehdal method

- Fat content by Soxhlet method

- Texture by Hedonic method

\subsection{Research procedure}

- White oyster mushrooms (Pleurotus ostreatus) sliced by hand and then mixed with spices consisted of onion, garlic, coriander, salt, pepper, brown sugar and thick coconut milk, stirred to be homogeneous.

- Unproductive quail meat ( $4000 \mathrm{~g}$ ) trimmed from fat and bone then steamed for 15 minutes and then divided to be 4 part and randomly will be giving white oyster mushroom as much as $0 \%$ (A), $10 \%$ (B), $20 \%$ (C) and $30 \%$ (D). Then stirred to be homogeneous and cooked for 60 minutes.

\subsection{Statistical Analysis}

The data obtained were analyzed by using analysis of variance (ANOVA). If there were the difference between the effect of treatment followed by Duncan's multiple range test (Steel and Torrie, 2007).

\section{Result and Discussion}

\subsection{Moisture}

Statistical analysis on Table 1 . showed that the adding white oyster mushroom was significantly $(\mathrm{P}<0.01)$ increased the moisture of Abon. It could be seen on treatment D that adding white oyster mushroom is highest (30\%) has increased moisture content of Abon significantly to be highest followed by the moisture content at treatment B and treatment A but not different with treatment $\mathrm{C}$. 
Table 1. Moisture Content of Abon

\begin{tabular}{ll}
\hline Treatment & Moisture (\%) \\
\hline A & $9.87^{\mathrm{a}}$ \\
B & $11.65^{\mathrm{b}}$ \\
C & $12.08^{\mathrm{bc}}$ \\
D & $12.91^{\mathrm{c}}$ \\
\hline
\end{tabular}

${ }^{\mathrm{abc}}$ Means with different superscript indicated significantly $(\mathrm{P}<0.01)$

The increase of white oyster mushroom given followed by the increase of Abon moisture content, because the white oyster mushroom contains a high moisture (90.97\%). The results are not consistent to Alik [8] research that the adding of white oyster mushroom up to $75 \%$ produces Tipia (oreochromis niloticus) Abon with the lower moisture content (7.38\%). Likewise the Laksono [9] research that the adding of white oyster mushrooms $50 \%$ on a chicken nugget, its moisture content is lower as $6.19 \%$.

In this study the use of white oyster mushrooms did not exceed $30 \%$ because in addition it contains high moisture, the water content of quail was even higher (78\%) than the water content of Tipia $(52 \%)$ and chicken $(60 \%)$. When white oyster mushrooms adding more than $30 \%$ will produce a higher Abon moisture, so that it can reduce the quality and shelf life of Abon. That's why even though the use of white oyster mushrooms in Alik's [8] and Laksono's [9] research is higher by $75 \%$ and $50 \%$ but the Abon moisture content produced is lower than the results of this study.

The moisture content at treatment $\mathrm{A}$ is lowest caused by the absence of white oyster mushroom in the Abon making, so that no additional water content in the Abon produced, so the moisture content is low. The moisture content of Abon by adding the white oyster mushroom in this study is higher than the moisture content Abon that recommended by the Indonesian National Standard 01-3707-1995 [2] where the maximum moisture content of Abon is 7\%

\subsection{Protein}

Statistical analysis on Table 2. showed that the adding white oyster mushroom was significantly (P<0.01) decreased the protein content of Abon. It could be seen on treatment D that adding white oyster mushroom is highest (30\%) in this study has decreased protein content of Abon significantly to be lowest followed by the protein content at treatment C, B and the highest protein content is at treatment A. Although there was a decrease in Abon protein content due to the use of higher white oyster mushrooms, but the Abon protein content in this study was higher than that recommended by the Indonesian National Standard 01-3707-1995 [2].

Table 2. Protein Content of Abon

\begin{tabular}{ll}
\hline Treatment & Protein $(\%)$ \\
\hline A & $29.27^{\mathrm{a}}$ \\
B & $28.71^{\mathrm{a}}$ \\
C & $26.76^{\mathrm{b}}$ \\
D & $25.51^{\mathrm{c}}$ \\
\hline
\end{tabular}

${ }^{\text {abc }}$ Means with different superscript indicated significantly $(\mathrm{P}<0 / 01)$

The decrease of protein content of Abon is in line with the increase of white oyster mushroom given, because white oyster mushroom contains a high moisture content is $90.70 \%$, thereby can be increase the moisture content of Abon was followed by decrease the protein content of Abon. In accordance with the statement that the levels of moisture is a factors that affect the decline of total solid which include protein and fat [10].

The results are consistent with Kurniawan [11] research, the higher the adding of white oyster mushroom up to $15 \%$ in meatball, the protein content decreased that is $16.89 \%$. Likewise, the addition of white oyster mushroom up to $50 \%$ in nugget, the protein content is lowest as $13.08 \%$ [9]. 
The protein content of Abon that added by the white oyster mushroom for all treatment in this study $(29.27 \%-25.51$ $\%$ ) are higher than the protein content that recommended by Indonesian National Standard 01-3707-1995 [2] where the minimum protein content of Abon is $15 \%$.

\subsection{Fat}

Statistical analysis on Table 3. showed that the adding white oyster mushroom was not influenced $(\mathrm{P}>0.05)$ the fat content of Abon. The adding of white oyster mushroom did not influence to the fat content of Abon caused by oyster mushroom has a low fat content is $1.6-2.2 \%$ with unsaturated fatty acids content more than $72 \%$ of the total fat [5].

Table 3. Fat Content of Abon

\begin{tabular}{ll}
\hline Treatment & Moisture (\%) \\
\hline A & $17.97^{\mathrm{a}}$ \\
B & $17.31^{\mathrm{a}}$ \\
C & $17.02^{\mathrm{a}}$ \\
D & $16.32^{\mathrm{a}}$ \\
\hline
\end{tabular}

${ }^{a}$ Means with same superscript indicated not significantly $(\mathrm{P}>0.05)$

Unsaturated fatty acid is a type of fatty acid that is easily oxidized or damaged during processing. As argued by Scrimgeour [12] that the unsaturated fatty acids cause the fat in the white oyster mushroom is easily oxidized. Fat oxidation is affected by the fatty acid composition, processing and storage conditions [13]. As a result, the addition of white oyster mushroom into the Abon of unproductive quail did not affect fat content of Abon for all treatment.

The Fat content of Abon for all treatments in this study has accordance to the quality standards specified by the Indonesian National Standard 01-3707-1995 [2] where the maximum fat content in Abon is $30 \%$, while the fat content of Abon in this research is $16.32 \%-17.97 \%$.

\subsection{Texture}

Statistical analysis on Table 4. showed that the adding white oyster mushroom was not influence $(\mathrm{P}>0.05)$ the texture of Abon.

\section{Table 4. The Texture of Abon}

\begin{tabular}{ll}
\hline Treatment & Texture \\
\hline A & $1.77^{\mathrm{a}}$ \\
B & $1.86^{\mathrm{a}}$ \\
C & $1.86^{\mathrm{a}}$ \\
D & $2.09^{\mathrm{a}}$ \\
\hline
\end{tabular}

\footnotetext{
${ }^{a}$ Means with same superscript indicated not significantly $(\mathrm{P}>0.05)$
}

The adding white oyster mushroom did not influence to texture of Abon because of white oyster mushroom have a soft texture and is easy to integrate with meat. As stated by Irnani [14] and Maulana [15] white oyster mushrooms have a texture that is similar to chicken meat that is springy and soft, white with a relatively neutral flavor, making it easy to integrate with various types of cuisine. As a result, the addition of white oyster mushrooms in the unproductive quail meat produces the same texture of Abon for all treatments, so the value of texture were not significantly different.

\section{Conclusion}

The adding of white oyster mushrooms is more economic in making Abon because it reduces the use of meat which its price is expensive. Although the Abon protein content produced decreases with the addition of white oyster mushrooms, the quality of Abon produced is still in accordance with the Indonesian National Standard 01-3707-1995, where the adding of white oyster mushrooms up to $30 \%$ has produced the moisture $(12.91 \%)$, protein $(25.51 \%)$ and fat (16.32 \%) and not reduce the texture of unproductive quail Abon. 


\section{References}

[1] Listiyowati and Roospitasari, K. (2000). Management for commercial cultivation of quail. Penebar Swadaya, Jakarta.

[2] Indonesian National Standard. 1995. Standar Nasional Indonesia. SNI 01-3707-1995. Abon. National Standardization Agency. Jakarta.

[3] Hilda, L.S. (2002). Utilization of breadfruit mixture with beef on moisture, protein and fat content, and abon texture produced. Thesis. Animal Science Faculty Andalas University, Padang.

[4] Suharjo, E. (2008). Cultivation of straw mushrooms in cardboard media. Journal of Food Technology Applications. Vol 1(4):115.

[5] Sumarmi (2006). Botanical and nutrition review of white oyster mushrooms. Agricultural Innovation Journal. Vol. 4, No. 2, (124-130).

[6] Widyastuti, N. and Istini, S. (2004). Optimization of the drying process of white oyster mushroom flour (Pleurotus ostreatus). Indonesian Pharmaceutical Sciences Journal.Vol. 2 (1):1-4.

[7] Steel, R.G.D and Torrie, J.H. (2007). Principles and procedures of statistics and biometrical. Mc Graw-Hill Book Company. New York.

[8] Alik, T.A. (2013). A Study on consumer acceptance of tilapia abon (oreochromis niloticus) with the addition white oyster mushroom (Pleurotus ostreatus). Universitas of Riau. Riau.

[9] Laksono, M. A. (2012). The water binding capacity, moisture, and protein of chicken nuggets substituted with white oyster mushrooms (Pleurotus ostreatus). Animal Agriculture Journal Vol. 1(1):691-692.

[10] Mahdian, E. and M. M. Tehrani. (2007). Evaluation the effect of milk total solid on the relationship between growth and activity of starter cultures and quality of concentrated yoghurt. Journal Agriculture and Environment Science 2 (5): 587-592.

[11] Kurniawan, A. (2011). Effect of Oyster Mushroom Addition (Pleurotus ostreatus sp) on Chemical Quality and Organoleptic of Chicken Meatballs. Universitas Sebelas Maret, Surakarta.

[12] Scrimgeour, C. (2005). Chemistry of fatty acids. Bailey's Industrial Oil and Fat products Inc. Scontland. Vol. 6(6): 119

[13] Ernawati, Purnomo, H and Estiasih T (2012). Antioxidant effects of liquid smoke on the oxidation stability of African catfish sausages (Clarias gariepinus) during storage. Journal of Agricultural Technology. Vol.13(2):120

[14] Irnani, M.F. (2014). Effect of comparison of gluten and white oyster mushrooms on the organoleptic quality of vegan sausages. Jurnal of Boga. Vol. 03(1):121.

[15] Maulana, P. (2013). Oyster Mushroom Harvest Season. A Complete Guide to the Business and Culture of Oyster Mushrooms.Lily Publisher, Yogyakarta. 